\title{
A Magyarország területén lehetséges drónalapú támadások szakmai és biztonsági kérdései
}

A dróntechnológia fejlődése az elmúlt időszakban egyre gyorsul, a fejlődés üteme - különösen a szoftveres alkalmazások terén - már-már exponenciálisnak nevezhető. Az ágazat hasonló, bár kisebb ívű fejlődésen megy keresztül, mint a mobil telekommunikációs eszközök az elmúlt 15 évben. Ez a jelenség többek között annak köszönhető, hogy egyre több szektor kapcsolódik be az ilyen típusú eszközök fejlesztésébe, gyártásába. Az ágazat tíz évvel ezelőtti húzó szegmensei (filmipar, térképészetet kiszolgáló eszközök, játékipar, mezőgazdaság) kiegészültek a hagyományos ipari területek képviselőivel. Ezeken a területeken megjelentek a főként szállítási feladatra tervezett eszközök, amelyek szinte kizárólag forgószárnyasok. A fejlődés menete a merevszárnyas eszközök esetében (SUAV ${ }^{1}$ területen) valamivel lassabb, mivel ezeknek az eszközöknek a fő felhasználási területe katonai jellegű. Mivel nincs közvetlen tömeges piaci értékesítés, valamint a felhasználói kör is szűkebb keresztmetszetű, ezért a piaci elvárásokból és a versenyből eredő folyamatos fejlesztési kényszer is gyengébb. Katonai területen a precíziós csapásmérésre alkalmas kamikaze drónok megjelenése jelent fordulópontot, mivel ezeknek a merevszárnyas eszközöknek az ára a hagyományos levegő-föld alkalmazású eszközöknek az ezrelékeiben mérhető. Az ilyen típusú eszközök akár órákon keresztül képesek a kijelölt légtérben tartózkodni, továbbá alkalmasak a támadás megszakítására, és a harci részt visszabiztosítva, az indítási helyre visszatérve újra bevethetők.

A pilóta nélküli eszközök fejlődését a szoftveroldalon tovább erősíti az alakfelismerő alkalmazások térnyerése, amelyek lehetővé teszik a teljesen önálló autonóm alkalmazást. Ezeknek a kamikaze eszközöknek a rendszerbe állítása és a kezelőállomány kiképzése eltörpül egy katonai repülőgép-vezető képzésének költségei mellett. Ha rendszeresítésre kerülnek, biztonságpolitikai szempontból elsősorban a területi igényekkel fellépő instabil politikai berendezkedésű országok jelentenek majd veszélyt. Ennek a problémának a vizsgálatával az elmúlt években több kutatóintézet (pl. a Jane's) foglalkozott. Az említett technológiai fejlő-

ÖSSZEFOGLALÁS: A drón alkalmazáson alapuló eljárások fejlődése során nemcsak a gazdasági élet szereplői előtt nyílhatnak meg új területek, hanem a nemzetközi terrorszervezetek is úi típusú terrorcselekményeket haithatnak végre. A hagyományos biztonsági struktúrákon túlmutatva, ezeknek a támadásoknak a kivédése mind technológiai, mind titkosszolgálati vonatkozásban új kihívásokat jelent.

KULCSSZAVAK: drón alapú eljárások, új típusú terrorcselekmények, tömeges dróntámadás, mikro légvédelem, drónelhárító rendszer, ISIS dés civil oldalról is veszélyt jelenthet, hiszen a szabályozás nélküli, rendezetlen viszonyok miatt, a potenciális elkövetői körök képesek lehetnek olyan eszközöket beszerezni, amelyek segítségével dróntámadásokat hajthatnak végre.

\section{ESEMÉNYEK ÉS TÁMADÁSOK AZ ELMÚLt ÉVEKBEN}

A pilóta nélküli forgószárnyas eszközök megbízhatóságának és teljesítményének fejlődése nyomán, már több mint 10 évvel ezelőtt megjelentek a piacon azok a forgószárnyas drónok, amelyek alkalmasak voltak kis tömegü hasznos teher célba juttatására. A szakterülettel foglalkozó szervezetek néhány képviselője már igen korán figyelmeztetett az új típusú eszközök által jelentett potenciális veszélyre, azonban mégis egy áldozatok nélküli akció kellett ahhoz, hogy felhívja a figyelmet a veszély tényleges mértékére.

2014 októberében, a Labdarugó Európa Bajnokság kvalifikációs mérkőzései során, a belgrádi Partizan stadionjába belebegett egy forgószárnyas eszköz, amelyre egy nagy Albániát ábrázoló zászló volt erősítve [1]. Az albán elkövetők az akció végrehajtására egy népszerű és nagyon elterjedt DJI2 Phantom típusú eszközt alakítottak át. A cél egyértelműen a szerb szurkolók provokálása volt, mégis a szakma képviselőin túl, a közvélemény előtt ez az esemény tette egyértelművé, hogy az új eszközök, egyben új típusú fenyegetettséget is jelentenek.

Szintén áldozattal nem járó tevékenység volt a Londont kiszolgáló gatwicki repülőtér közelében, 2019 decemberében bekövetkezett esemény. Az egy pályával rendelkező diszkont repülőtér több napra megbénult a bevezető légifolyosótól nem messze feltűnő drónok miatt. A brit nemzetgazdaság több százmillió fontos veszteséget szenvedett el, valamint az amúgy is zsúfolt légtérszerkezet ideiglenes áttervezése további, dominóhatást váltott ki. Az esemény 1000 járatot és 140000 utast érintett [2]. A helyzet megoldására a hadsereg elektronikai hadviseléssel foglalkozó speciális alakulatainak, valamint a titkosszolgálatok együttes akciójára volt szükség. Az akció során olyan civil személyeket

ABSTRACT: During the development of drone technology, new fields of opportunity have opened up not only for the various participants of the economy but also for international terrorist organisations, whoare now able tocarry out new types of acts of terror. Going beyond conventional security frameworks, averting these attacks means new challenges from the perspective of technology and the secret services.

KEY WORDS: drone technology, new type os acts os terror, mass drone attack, micro air defence, anti UAV system, ISIS

\footnotetext{
Katonai szakértő. ORCID: 0000-0002-1043-7076
} 


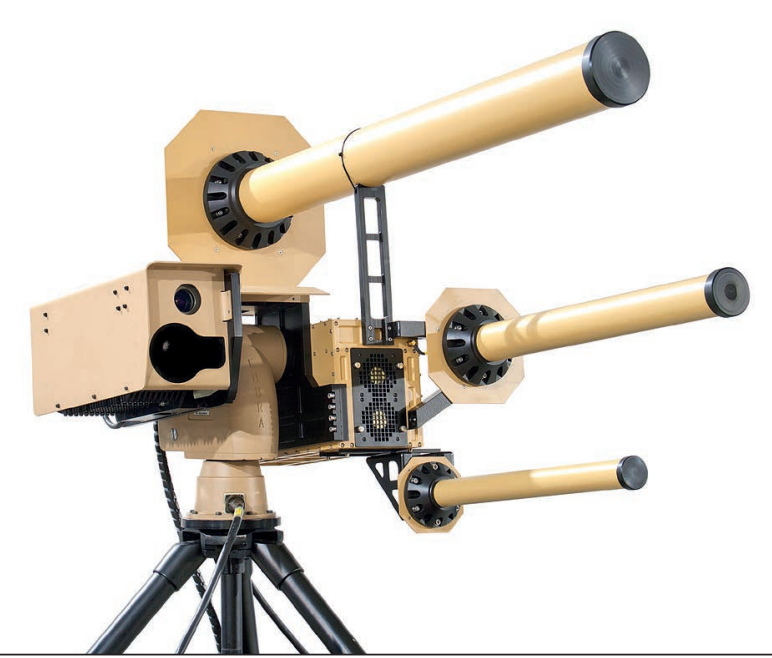

1. ábra. Brit vállalatok együttmüködéseként fejlesztett, a Gatwick-i repülőtérre telepített drónelhárító (Anti UAV Drone - AUDS) rendszer (Forrás: basecuritysystem.co.uk)

vettek őrizetbe, akik nem rendelkeztek semmilyen komolyabb technikai képzettséggel, és terrorszervezetekkel sem tartottak fenn kapcsolatot. Ez a tény azért figyelemre méltó, mert ha ilyen „amatőr” elkövetők ekkora problémákat voltak képesek okozni, akkor el lehet képzelni, hogy egy műszaki háttérrel rendelkező, szervezett elkövetői csoport milyen nagyságrendű akcióra lenne képes. Az incidenseket követően a repülőtér több millió fontos fejlesztéseket hajtott végre, amelyeknek köszönhetően fixen telepített drónelhárító rendszerrel védik - elsősorban a pálya két végén található - leginkább veszélyeztetett területeket. (1. ábra.)

Figyelemfelkető ellenséges akció volt a Szaúd-Arábia területén 2019. szeptember 14-én végrehajtott támadás [3]. A két központi olajfinomítóban, Abkaikban és Huraiszban végrehajtott támadást merevszárnyú eszközökkel követték el. A jelentős termeléskiesést okozó cselekmény komoly előkészületet feltételez, mivel a létesítmények stratégiailag fontos részeit, jól megválasztott berepülési útvonalakon érkező eszközök tették tönkre. A valószínűleg houth nemzetiségü ${ }^{3}$ [3] elkövetők által indított eszközök ellen a szaúdi integrált légvédelmi rendszer képtelen volt tevékenykedni, hiszen ezeket a rendszereket nem az alacsonyan repülö, kis visszaverő felülettel rendelkező, pilóta nélküli eszközök ellen fejlesztették ki.

\section{A HUMÁN FAKTOR JELENTŐSÉGE}

Az Iszlám Állam terrorszervezet létrejötte, gyors szervezeti fejlődése és hatékony toborzási tevékenysége ismételten bebizonyította, hogy saját társadalmainkhoz hasonlóan, a terrorszervezeteknél is generációváltás megy végbe. A komoly műszaki problémákat is megoldani képes terroristák létezésére az első kézzelfogható bizonyíték az Amerikai Egyesült Államok területén felkészülő terrorcsoportot vezető Mohamed Atta alakjának megjelenése. Az egyiptomi Atta a Hamburgi Műszaki Egyetem egykori hallgatójaként [4] képes volt a szeptember 11-i terrorcselekmények operatív végrehajtását hatékonyan megtervezni, és a végrehajtást összehangolni. A terrorszervezet egyik meghatározó alakjának, Khalid Sheikh Mohammed alapötletét tovább fejlesztve, mérnökként megvizsgálta a leghatékonyabb becsapódási szögeket, valószínűleg rájött az égő üzemanyag és a teherviselő acélszerkezetek közötti összefüggésre. Megtervezte a repülési útvonalakat, a támadást a legapróbb részletekig kidolgozta és még olyan apróságokra is odafigyelt, hogy légiforgalmi szempontból a legnehezebben átlátható területen kapcsolja ki a transpondert (radar-válaszjeladót).
Az ISIS ${ }^{4}$ megjelenését követően olyan európai műszakiinformatikai felsőoktatásban végzett személyek is csatlakoztak a terroristákhoz, akik tudása alkalmas annak a tanulási folyamatnak a végigvitelére, amely a dróntámadások végrehajtásához szükséges. Ezeknek a személyeknek az egyéni fejlődésében meghatározó lehet, hogy az ISIS berkein belül az iraki hadsereg egykori szunnita tisztjeitől azt is megtanulhatták, hogy miként tervezzék meg hatékonyan a saját csoportjuk tevékenységét [5]. Az ISIS széthullását követően, a szervezet egykori tagjai Európába hazatérve, az elsajátított ismeretek birtokában tervezhetik meg újabb támadásaikat immáron az Európai Unión belül. Olyan elkövetői körről van szó, amelynek tagjai képesek a saját maguk által végzett tevékenységeket objektíven kiértékelni, és a levont következtetéseket megfelelően hasznosítani. Az alapvető (forgószárnyas) dróntechnológia az ISIS tagjainak nem ismeretlen, hiszen azt a szervezet által készített több propagandavideóban is alkalmazták, illetve kísérleti jelleggel hagyományos gravitációs bombavetéssel is próbálkoztak (erről az akcióról az egyik legnagyobb videomegosztó oldalon ma is elérhetők a felvételek). (2. ábra.) A lehetséges dróntámadások sikeres végrehajtása során az elkövetők részére inkább az EU területén történő előkészítés, mint a technikai végrehajtás jelenti a nagyobb kihívást.

A potenciális elkövetők toborzása során lényeges szempont, hogy bár az eszköz megsemmisül, az elkövető azonban túléli a támadást és nagy valószínúséggel elkerüli a közvetlen elfogást is. Egy sikeres, vagy sikertelen támadást követően a tapasztalatok kiértékelhetők, így az elkövetői kör képes lehet az eszközök alkalmazásának folyamatos fejlesztésére. (Bár jóval szerényebb technológiai környezetben, de ilyen jellegű fejlődést láthatunk az elmúlt években az improvizált robbanóeszközök készítése és „kreatív” alkalmazása terén is.)

A terrorcselekmények elkövetői soraiban is megjelent a Z generáció. Ez a korosztály internet alapú társadalomba született, és szocializációjának jelentős része a (radikális) közösségi médián keresztül zajlott. Az információk azonnali megosztása, a képi anyagokban történő kommunikáció fontossága ennek a korosztálynak alapjaiban meghatározza a gondolkodásmódját. Ennek az új típusú gondolkodásmódnak a megjelenése jól nyomon követhető az európai célpontok kiválasztása során. A Nizzában és Barcelonában végrehajtott terrortámadások alkalmával a szemtanúk képeket és videókat töltöttek fel mobiltelefonjaikról a közösségi médiafelületekre. A terroristák fő célját, a félelemkeltést (a közösségi médián keresztül) nagyobb átütő erővel próbálják megvalósítani, amire az Ariana Grande ${ }^{5}$ manchesteri koncertjén elkövetett öngyilkos robbantásos merénylet szolgált példaként. Az elkövetők részéröl a rendezvény kiválasztása is tudatos lehetett, mivel Ariana Grande elsősorban a Z generáció kedvence, annak a generációnak, amelynek tagjai a koncertről a külvilág számára szinte online közvetítették okostelefonjaikon a merényletet követő percek szörnyű eseményeit. (A merényletben 23-an meghaltak, közel 120-an megsebesültek.) A megosztások exponenciálisan növelték a merénylet másodlagos pszichológiai hatásait. A koncertet követően megjelent ISIS által készített montázs ábrázoláson a merénylet eszközeként már repeszgránátokkal felfegyverzett drónok láthatók.

\section{MAgYARORSZÁG VESZÉLYEZTETETTSÉGÉNEK MÉRTÉKE ÉS JELLEGE}

Hazánkban nincsenek jelen a radikális iszlám követői. Magyarország veszélyeztetettségét a kormány biztonság- és külpolitikája, továbbá a hagyományos keresztény értékek 


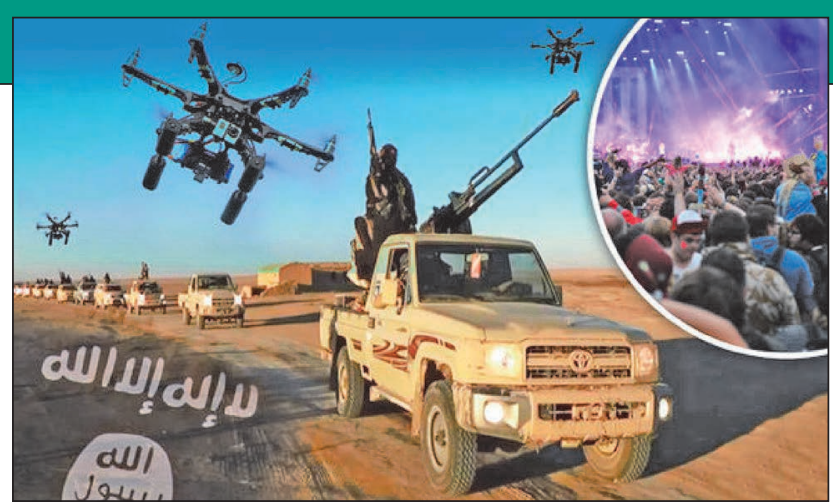

2. ábra. A közösségi médiafelületeken megjelenő, ISIS propagandaanyag (Forrás: Facebook)

védelme és azok nemzetközi színtéren történő intenzív kommunikációja határozza meg. Az ország által képviselt értékek az iszlám társadalmakba visszatérő európai terroristák körében szimbolikus célponttá válhatnak. Az ilyen jellegű célpontokon túl az ipari területek is egyre nagyobb fenyegetettségnek vannak kitéve. A 2019-ben bekövetkezett, Szaúd-Arábia központi kőolajfinomítója ellen elkövetett összehangolt dróntámadás ismételten felhívta a figyelmet az érzékeny ipari célpontok (hazánk esetében például: Paks) sebezhetőségére. Magyarország rend- és honvédelmi szervei rendelkeznek a védelemhez szükséges eszközökkel, eljárásrenddel és jogszabályi felhatalmazással a védekezéshez, illetve ezek további fejlesztése jelenleg is folyamatban van. Magyarországon leginkább egy szimbolikusnak tekinthető országos vagy nemzetközi esemény, illetve nagy médiafelületen megjelenő tömegrendezvény lehet nagyobb veszélynek kitéve.

Az 1938-as sikeres megrendezése után, 2021-ben ismét Magyarország ad otthont az Eucharisztikus Kongresszusnak. Ez a rendezvény az utóbbi időben a modern keresztény világ legnagyobb tömegrendezvényévé vált, jelentőségét jól mutatja, hogy a legutóbbi, Ázsiában megrendezett világkonferenciának volt olyan napja, ahol több mint 1 millió katolikus hívőt regisztráltak. A COVID-19 világjárvány miatt az eredetileg 2020-ra tervezett rendezvényre a tervezettnél kisebb látogatószámot várnak, azonban még így is az utóbbi évek legnagyobb tömegrendezvényének ígérkezik hazánkban.

\section{LEHETSÉGES ELKÖVETÉSI MÓd ÉS VÉDELEM}

A terrorcselekmények egyik gyakori elkövetési módja, amikor az elkövetők forgószárnyas eszközt, vagy eszközöket vetnek be. Ennek oka a könnyű elérhetőségben és a „felhasználóbarát" alkalmazásban keresendő. Olyan eszközöket alkalmazhatnak, amelyek képesek külső függesztmény, vagy hasznos teher hordozására. Mivel a hordozóeszközök is megsemmisülnek, ezért nincs szükség bonyolult célzóberendezés létrehozására sem.

Az utóbbi időszakban, a piac bővülésével párhuzamosan egyre könnyebbé válik a középkategóriás pilóta nélküli eszközök beszerzése. A nyilvántartási rendszerek hiánya nemcsak az alkalmazásra, hanem a piaci értékesítésekre is hatást gyakorol. Reális a veszély, hogy hamis, vagy lopott adatokkal beszerezhető olyan eszköz, amelyre kis tömegű robbanótest szerelhető. Ezeknek a beszerzése egyszerűen megvalósítható, így az illegális fegyverbeszerzéseknél megfigyelhető fiktív fedőszervezetekre sincs szükség. ${ }^{6}$ A támadásra történő felkészülés rendkívül egyszerüen, egy kis méretű forgószárnyas eszközzel megoldható, a végrehajtás előtt mindössze néhány tesztrepülés szükséges a súlyhatárok és a manőverezőképesség, valamint az adatátvitel erősségének ellenőrzése céljából. (3. ábra.) Az elkövetők számára nagyobb kihívást jelenthet a kis méretű

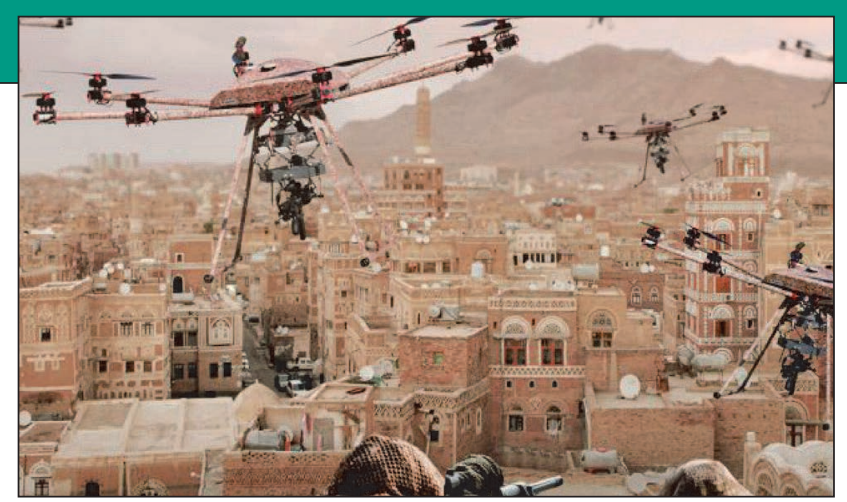

3. ábra. Tömeges dróntámadást ábrázoló montázs [6]

repeszgránát, és az ahhoz illeszkedő gyújtószerkezet elkészítése. A balkáni fegyverkereskedő csatornákon keresztül napjainkban is bejuttathatók Európába olyan katonai eszközök, amelyek átalakításával a harci rész megvalósítható.

Az elkövetői oldalt vizsgálva, a legkomolyabb problémát azok az ISIS-ből hazatérő második generációs fiatalok jelentik, akik a szervezetnél folytatott tevékenységük során megtanulták az improvizált robbanóeszközök készítésének alapjait. Ilyen alapismeretekkel rendelkező személy képes arra, hogy olyan harci részt készítsen, amely az adott eszköz súlykorlátaiba belefér, és nagy biztonsággal képes működni. Mivel az ilyen típusú tevékenységeknél kamikaze drónként alkalmaznak egy alapvetően nem erre a célra fejlesztett gépet, ezért kioldó szerkezetre sincs szükség, ami tovább egyszerűsíti az eszköz elkészítését és működtetését. Fontos megemlíteni, hogy a másodlagos pszichológiai hatás miatt valószínűleg a támadást magáról ez eszközről is filmezni fogják, és az így készített felvételeket a későbbiekben promóciós anyagokban is felhasználhatják.

\section{A tÁMADÁS ELKÖVETÉSÉNEK LEGVALÓSZÍNÜBB TEÓRIÁJA, ÉS A VÉDELEM TÍPUSAI}

A célterület felderítése, valamint a támadás helyének és időpontjának meghatározása során, a kiválasztás két irányból történhet. Technikai oldalról kiemelt szempont a hordozó gépjármű optimális távolságban, a célpont közelébe történő kijuttatása, az eszköz feltűnésmentes indítása, illetve a rávezetés akadály- és zavarásmentes végrehajtása. (Az elkövetők szempontjából ez tekinthető a leggyengébb pontnak.) Az utóbbihoz egy olyan magaslati (épület) pont kiválasztása szükséges, ahonnan a vezérléshez szükséges kimenő jel megfelelő erősségű. Ennek a pontnak a kiválasztása során az elkövetők valószínűleg az optimális menekülési útvonalakat és módokat is feltérképezik. Bár megvalósítható, mégsem valószínű, hogy GPS-koordináták alapján, előre programozott útvonalon történjen a rávezetés. A hatékony védelem mellett szól, hogy az utóbbi időben a GPS-zavarásra képes eszközök komoly fejlődésen mentek keresztül. $A z$ ilyen típusú eszközök kezelőit a megfelelő helyre telepítve, hatásos védelmet képesek biztosítani a nyilvános rendezvények számára abban az esetben, ha az elkövetést GPS-alapú eszközzel kísérlik meg. Közvetlen vezérléssel működő eszközök esetén az elhárítás szempontjából a legnagyobb kihívást az alkalmazott frekvenciák felderítése jelenti. A jelenleg fejlesztés alatt álló, vagy a már rendszerbe állított eszközök egy erősen korlátozott, adott adatbázisból képesek működni. Az elkövetők a legbiztosabban akkor tudják végrehajtani a támadást, ha egy kis szériában gyártott, ismeretlen, különböző helymeghatározó rendszerek között váltani képes eszközt választanak. Mivel a dróntámadások rövid idő alatt lezajlanak, ezért a támadást végrehajtó eszköz vizuális érzékelésére, a drón által használt frekvenciák felderítésére, illetve az ellentevékenység megkezdésére rendkívül kevés idő áll rendelkezésre. (4. ábra.) 


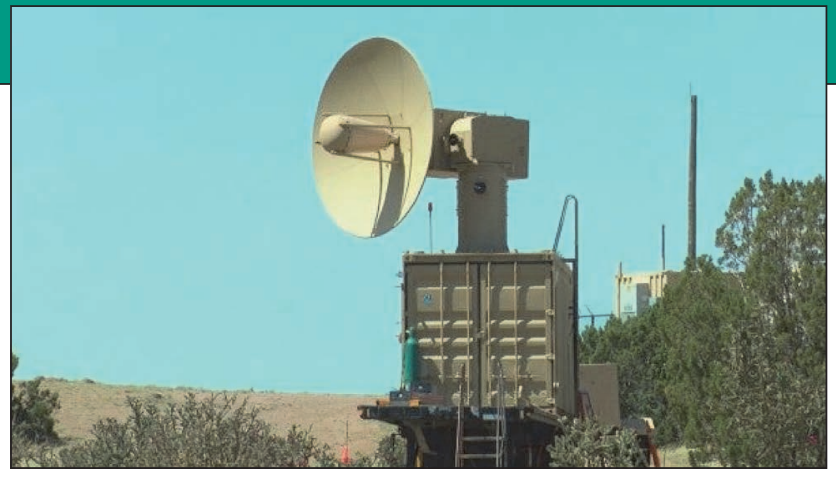

4. ábra. Az USAF által üzemeltetett mikrohullámú THOR rendszer, „konténeres" telepítésben [7]

Jelentős fejlődés ment végbe az impulzus alapú fegyverek terén. Ezen eszközök közé tartozik Raytheon által fejlesztett nagy teljesítményű mikrohullámú HPM (HighPower Microwave) komplexum is. Mivel a rendszer a térben aránylag nagy felületen dolgozik (lefedi a tér egy részét), ezért hatásos lehet a tömeges támadás elleni védelem során. Működési elvét tekintve, két fokozatban frekvencia- és rádiókommunikációs zavarást hajt végre. $\mathrm{Az}$ erősebb kimenő teljesítmény esetén már nem a kapcsolat leválasztása, hanem az eszköz károsítása a cél.

A bemutatott biztonsági problémák megoldására az elfogó drón alkalmazása is felmerülhet. Az elfogó drónok feltünése, a kezdeti látványos bemutatók után a közelmúltban visszaesett. A visszaesés fő oka az „egy az egy ellen” történő alkalmazás alapvető korlátjaiban keresendő. A drón alapú támadások fő motívumát adó „túlterheléses csapásmérés" esetén ugyanis az elfogó drón nem vethető be. Az alapvetően nagy magasságban repülő merevszárnyas pilóta nélküli eszközök elhárítása során - felhasználási korlátai miatt - az ún. HEL- (High-Energy Laser) rendszerek sem jöhetnek szóba a tömegrendezvények biztosítása során.

\section{Az AZONOSÍTÁS PROBLÉMÁJA}

A nagy televíziós, valamint internetes médiafelülettel rendelkező rendezvények egy további problémát is fölvetnek a védelem megszervezése terén. Ez a probléma a levegőben egyszerre jelen lévő több (legalább $5 \mathrm{db}$ ) pilóta nélküli eszköz, amivel az adott terület mikro légtere túlzsúfolttá válik. Ilyen szempontból hazánkban leginkább talán a könnyűzenei fesztiválok a legveszélyeztetettebb rendezvények. Az elsősorban a fiatalokat érintő tömegrendezvényeken megjelenő kis méretű forgószárnyas eszközöket nemcsak a média képviselői, hanem magánszemélyek is alkalmazzák. Ezeken a fesztiválokon nemcsak a televíziótársaságok, hanem internetes bloggerek, valamint „Youtube személyiségek" is készítenek videós tartalmakat, amikhez forgószárnyas eszközöket használnak. A levegőben egyszerre jelen lévő eszközök miatt a támadás végrehajtására alkalmas drónok képesek „elvegyülni”, ezért a jövőben a mikro légvédelmek tervezésekor is foglalkozni kell a barát-/ ellenség-azonosítás kérdésével.

\section{MEGELŐZÉS ÉS FELKÉSZÜLÉS}

A dróntámadások lehetősége napjainkra már nemcsak fikció, hanem valós veszélyforrás. A sikeres elhárítás alapfeltétele a rugalmasan telepíthető mikro légvédelmi rendszerek folyamatos fejlesztése. A hatékony védelem kulcsa a hatékony együttműködés. A jövőben az elektronikai hadviselés és pilóta nélküli eszközök területén jártas szakembereknek folyamatosan együtt kell dolgozniuk a titkosszolgálatok munkatársaival annak érdekében, hogy a lehetséges „elkövetői trendekre" a lehető leggyorsabban

tudjanak felkészülni, majd reagálni. Mivel műszaki szempontból a terrorcselekmények elkövetői nem hagyományos sémák mentén gondolkoznak, ezért a védelmet tervező szakembereknek is képesnek kell lenniük nem hagyományos sémákat alkalmazva, kreatív módon leküzdeni az ismeretlen veszélyeket.

\section{HivATKOZOTT IRODALOM}

[1] „People behind drone chaos had ,detailed knowledge of Gatwick." The Guardian, 2019. 09. 17. Elérés: 2021. 01. 15. https://www.theguardian.com/uk-news/2019/ sep/27/gatwick-drone-disruption-perpetratorsdetailed-knowledge-airport-police-report;

[2] „Serbia vs Albania Euro Qualifier: Shadowed by Past and DJI Phantom Drone" Drone examiner 2015.01.12. Elérés: 2021. 01. 15. http://www.droneexaminer.com/ drone-news/serbia-vs-albania-euro-qualifiershadowed-by-past-and-dji-phantom-drone.html;

[3] „Saudi Arabia oil facilities ablaze after drone strikes" BBC 2019. 09.14. Elérés: 2021. 01. 15. https://www. bbc.com/news/2019/sept/14;

[4] „Inside The Terror Network / Mohamed Atta" PBS Frontline. Elérés: 2021. 01. 15. https://www.pbs.org/ wgbh/pages/frontline/shows/network/personal/ whowere.html;

[5] Coles, Isabel és Ned Parker. „How Saddam's men help Islamic State rule" Reuters Investigates 2015. 12.11. Elérés: 2021. 01. 15. https://www.reuters.com/ investigates/special-report/mideast-crisis-iraqislamicstate/;

[6] Cardinal, David. „Killer Robot Drones are Coming to a Military Near You" ExtremeTech 2017. 08. 14.

Letöltés: 2020. 12. 12. https://www.extremetech.com/ extreme/254106-killer-robot-drones-coming-militarynear;

[7] Liptak, Andrev. „The US Air Force has a new weapon called THOR that can take out swarms of drones" The Verge 2019. 07. 21. Letöltés: 2020. 12. 21. https:// www.theverge.com/2019/6/21/18701267/us-air-forcethor-new-weapon-drone-swarms.

\section{JeGYZETEK}

1 Small Unmanned Air Vehicle (SUAV) - kis méretủ pilóta nélküli légi jármü.

2 Shenzhen Dajiang Baiwang Technology Co., Ltd. - Kínai székhelyú multinacionális vállalat (https://www.dji.com/hu/company).

3 A magyar sajtóban általában húszi vagy húti lázadókról olvasunk. A Houth egy iszlám politikai és fegyveres mozgalom, amely az 1990-es években Sa'dah-ból jött létre Jemenben, alapítója a Houthi törzsből származott (a szerk.).

4 Islamic State of Iraq and Syria - Iszlám Államként is ismert szunnita dzsihádista terrorszervezet.

5 Ariana Grande-Butera (1993-) amerikai színész, énekes, dalszerző. 6 A tanulmányt a szerző a pilóta nélküli légi járművekre vonatkozó jogszabályok 2021 januári változása előtt írta, a fenti megállapítás a korábbi jogszabályi környezetben helytálló. 2021. január 1-től Magyarországon csak a HungaroControl mobilalkalmazásának használatával reptethetők a pilóta nélküli légi járművek. A törvény értelmében a légiközlekedési hatóság nyilvántartásba veszi a drónokat és üzembentartóikat is, és attól kezdve a magyar légteret kizárólag a nyilvántartásba vett járművek használhatják (a szerk.).

7 A kötelező regisztrációról szóló új szabályozás ebben az irányban is bizonyos védelmet jelent, hiszen a kritikus légtérbe belépő azonosítatlan légi jármúvet eleve fenyegetésnek lehet tekinteni. 